Reprod. Nutr. Dévelop., 1980, 20 (4 B), 1125-1141.

\title{
Neurohumoral control of gastrointestinal motility
}

par C. ROZÉ

Laboratoire de Biologie et Physiologie des Cellules digestives, (FRA 49 INSERM), Faculté de Médecine X Bichat, 16, rue H.-Huchard, 75018 Paris, France, et Université P.-eł-M.-Curie

Summary. The progress of gastrointestinal physiology is presently dominated by the concept of neuroendocrine regulation and the control of motility is in keeping with this concept.

Progress in biochemistry, immunocytochemistry and radioimmunoassay in the past few years has produced a whole new collection of peptide molecules extracted from the digestive tract. Two facts are evident from these new data : (i) many peptides in the gastrointestinal tract are present in both endocrine cells and nerve fibers, and (ii) many peptides are found in both the brain and the gastrointestinal tract. There is thus a large wave of interest in the so-called brain-gut axis and in the relations between brain and gut and between nerves and hormones.

The motile system of the gastrointestinal tract is a complex whole having several organizational levels. The morphological, fixed structure is a « cable » network comprising smooth muscle and intrinsic and extrinsic nerves. Control feedback loops may be evidenced at all levels-muscular, intrinsic, ganglionic and central. Local concentrations of circulating (endocrine) or paracrine peptides may act as modulators of this basic pattern by contributing to the depolarization or the hyperpolarization of smooth muscle cell membranes. The mode of action of these peptides reveals at least two different kinds of receptor sites : one on the smooth muscle cells and the other on the axons or cell bodies of intramural excitatory or inhibitory neurons. In addition, central nervous system effects may centrally modulate the long pathway reflexes travelling in the main vagosympathetic trunks. It is no longer possible to separate completely the neural from the hormonal in studying motility control. The whole neuroendocrine control complex must be investigated.

\section{Introduction.}

The changing picture of gastrointestinal physiology is dominated at present by the neuroendocrine regulation concept, and digestive motility does not escape this influence.

At the end of the 19th century, nervous control of digestion seemed to be demonstrated by the work of Pavlov. In 1902, Bayliss and Starling discovered secretin and digestive hormonology made such great strides that, except for obvious vagal effect on the stomach, nervous system influence was practically forgotten by the new digestive endocrinologists. 
Due to progress in biochemical methods of extracting, analyzing and synthesizing peptides, the structure of a whole new series of peptide molecules from the digestive tract has been successively determined. Besides the usual three main hormones (gastrin : Gregory et al., 1964 ; secretin : Mutt, Jorpes and Magnusson, 1970 ; cholecystokinin : Mutt and Jorpes, 1971), another series of molecules has been successfully sequenced and sometimes synthesized : e.g. VIP (vasoactive intestinal peptide, Mutt and Said, 1974), GIP (gastric inhibitory peptide, or better, glucose-dependent insulinotropic peptide, Brown and Dryburgh, 1971), motilin (Brown, Cook and Dryburgh, 1973) and pancreatic polypeptide (Hazlewood et al., 1973 ; Lin, Chance and Evans, 1973). Since all the gastrointestinal hormones known were peptides, it was supposed that all peptides isolated in the digestive tract were hormones.

Due to progress in immunocytochemistry, radioimmunoassay and radioreceptor assay, two facts have emerged which support this supposition : (i) some gastrointestinal peptides are not only present in endocrine cells but also in nerve cells, (ii) some peptides are present in both the digestive tract and the central nervous system.

In spite of the work of Von Euler and Gaddum (1931) on substance-P, that peptide was only sequenced in 1971 from brain extracts (Chang, Leeman and Niall) and in 1973 from intestinal extracts (Studer, Trzeciak and Lergier). The discovery of somatostatin in gastrointestinal and pancreatic D-cells in 1975 led physiologists to study brain-gut relations (the brain-gut axis) and also revived an interest in the effects of the nervous system on the gut, even if those effects were sometimes peptide-independent.

Several families of peptides common to both the central nervous system (CNS) and the digestive tract (DT) may be distinguished. The first ones isolated and sequenced from both the brain and the DT were substance P (Chang, Leeman and Niall, 1971 ; Studer, Trzeciak and Lergier, 1973) and neurotensin (Carraway and Leeman, 1975 ; Kitabgi, Carraway and Leeman, 1976).

Other peptides first isolated in the DT, then found in the brain by immunoassay are CCK (Dockray, 1976), VIP (Bryant et al., 1976), motilin (Yanaihara ef al., 1978). In the reverse, isolated brain peptides have been found in the DT by immunoassay : somatostatin (Arimura ef al., 1975), enkephalin (Polak et al., 1977), TRH (Morley et al. 1977).

Bombesin, a special case, was first isolated in amphibian skin and then found in. the brain (Brown ef al., 1978) and the DT (Erspamer ef al., 1978).

Due to the rapid progress in this field, this review is necessarily incomplete and inexact because peptides often have several molecular forms, complicating their analysis, as in the case of somatostatin which has various origins (Spiess and Vale, 1978 ; Pradayrol, Chayvialle and Mutt, 1978 ; Chayvialle et al., 1979).

This dual origin raises several questions as to how peptides function as chemical transmitters. Some are present in both the nerve fibers and the endocrine cells

\section{TABLE 1}

Peptides localized in both endocrine cells and nerve fibers.

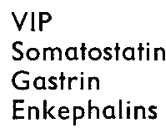


(table 1); most have measurable circulating levels in physiological conditions (table 2).

TABLE 2

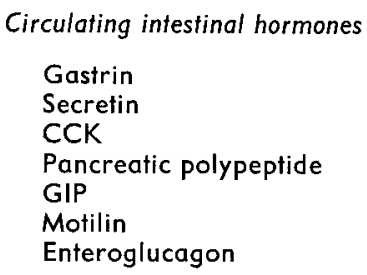

Peptidic chemical transmission occurs in three ways : (i) the usual endocrine action by blood pathway diffusion, (ii) neurocrine action by transmitter diffusion through a synaptic space, and (iii) paracrine action triggered by diffusion of a cellular peptide to the neighboring target cells, accomplished through the intercellular space without passing by the blood route.

Due to these discoveries, all physiologists at present recognize that nervous and humoral factors are equally important in digestive regulation, and that it is thus difficult to dissociate them owing to their intricacy; neuroendocrine potentialization appears to be the rule in physiological conditions.

Three interactions have been clearly demonstrated : hormonal release by the nerves (examples : gastrin, pancreatic polypeptide), modulation of the response to nervous stimulation (example : «permissive » gastrin levels are requisite if the gastric parietal cell is to respond optimally to vagal stimulation), hormonal action by

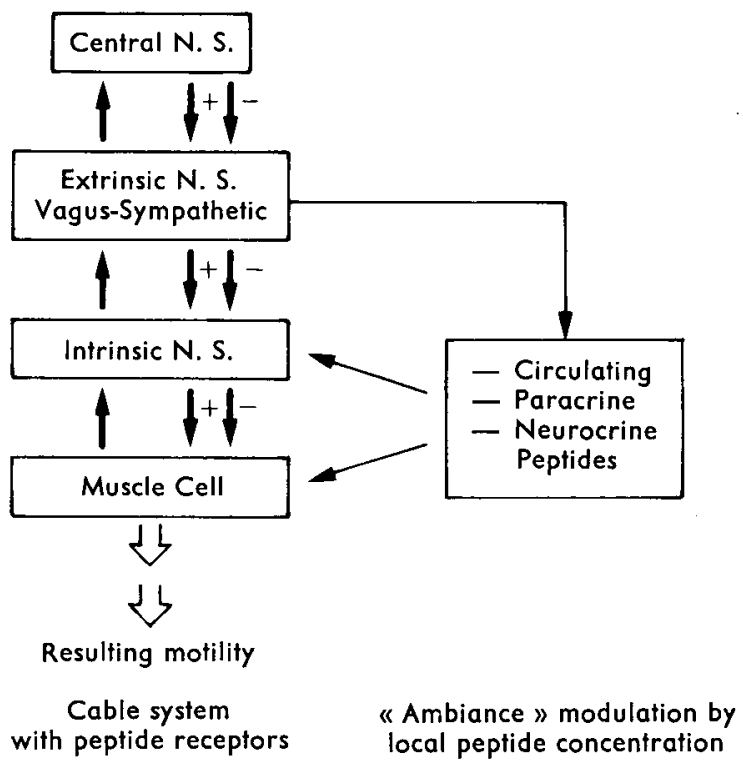

Fig. 1. - Diagram showing regulation of digestive motility. 
nerve fiber intermediary (example : relaxation of the lower esophageal sphincter LES - induced by octo-CCK in the cat and in humans).

The system regulating digestive motility is thus a complex one (see diagram in fig. 1). The anatomic neuromuscular whole is a fixed system which we will call a " cable »system with its sensorimotor inhibitors and excitors and its successive organizational levels which are at least three in number. The intestinal smooth muscle has autonomous myogenic activity and its own receptors. Its innervation includes the intrinsic wall plexus, the coeliac and mesenteric ganglia, which integrate some data, and the central nervous system with its cables of vagal and sympathetic pathways. This basic structure is under hormonal control, each peptide theoretically being able to act at each of the preceding organizational levels, including participation in possible synaptic transmission.

Each effector is thus controlled by the local result of the sum of the concentrations of the numerous agonists and antagonists (peptides or neurotransmitters) present, each of which is often only relatively specific for the effector receptors because the peptide structures, although different, have common partial sequences. We have called this «ambiance » modulation, indicating by this rather vague term the many factors - such as circulating peptide level, distribution of blood flow, binding by non-specific elimination sites, presence of other agonists or antagonists, receptor turnover - which could play a role in the local regulation of a peptidic agonist near an effector site.

Such complexity explains why present studies often only describe or analyze an action and do not present a synthesis of the whole. It also justifies the large number of research teams which, stunned by the complexity of this problem in vivo, prefer to study very simple preparations, isolated in a test-tube, although they may be spending time on theoretical studies of peptide receptor binding having only a secondary importance in physiological conditions in vivo.

We shall try to analyze briefly the levels of this «cable» system and its peptidic modulation.

\section{Myogenic activity or muscular level.}

The intestinal smooth muscle cells are spindle-shaped and mononucleated; as compared to the striated muscle cells, their contractile filaments are poorly organized. Moreover, they have a spontaneously oscillating membrane potential which conditions a high degree of spontaneous, myogenic, independent rhythmic activity.

Some smooth muscles (stomach of carnivores such as the pig, monkey and man) show « plateau » action potentials, including rapid depolarization followed by slow repolarization. The plateau may be overloaded with rapid oscillations, but this phenomenon is not constant and the amplitude of slow depolarization conditions the contractile force (see Gonella, 1978). Other muscles such as those of the small intestine and some in the stomach and colon show slow, permanent oscillations, or slow waves, which are only accompanied by contractions when they are overloaded with spike potentials. In both cases, the contractile machinery is only activated when depolarization reaches a sufficient level (spike or plateau). The maximum result is that contractions appear at the same rhythm as the periodic oscillations of the membrane potential. 
It is probable that most intestinal smooth muscle cells have the intrinsic property of oscillating spontaneously. A cell, however, does not oscillate alone because it is connected to others by low-resistance junctions; the whole can thus function physiologically as a syncitium. Morphologically, these are gap junctions, also called « nexus ». They aid in conducting the stimulus from one cell to another, and explain why potentials with a shape and polarity comparable to those recorded by intracellular microelectrodes can be recorded with extracellular electrodes.

The gastrointestinal smooth muscle thus acts as a network of coupled oscillators. All the properties of intestinal slow waves can be reproduced by simulating this principle (Sarna, Daniel and Kingma, 1971, 1972). The oscillator with the highest intrinsic frequency usually imposes its rhythm on the neighboring cells, thus explaining the frequency plateaus and decreasing frequency gradients found from the duodenum to the ileum. However, in some cases, oscillator coupling is more complicated, as shown in table 3 from Daniel (1977).

TABLE 3

Localization of main myogenic oscillators and their action on other spontoneously oscillating fibers (from Daniel, 1977)

\begin{tabular}{|c|c|c|c|c|}
\hline Zone & $\begin{array}{l}\text { Localization of high- } \\
\text { frequency oscillator }\end{array}$ & $\begin{array}{l}\text { Type of lowe } \\
\text { oscillator }\end{array}$ & $\begin{array}{l}\text { r frequency } \\
\text { response }\end{array}$ & \\
\hline Stomach & $\begin{array}{l}\text { Proximal : greater curvature } \\
\text { of the gastric body }\end{array}$ & Phase locked & & \\
\hline $\begin{array}{l}\text { Proximal small intestine } \\
\text { Distal small intestine } \\
\text { Proximal colon }\end{array}$ & $\begin{array}{l}\text { Proximal duodenum } \\
\text { Proximal } \\
\text { May be distal }\end{array}$ & $\begin{array}{l}\text { Phase locked } \\
\text { Pulled up } \\
\text { Pulled up } \\
\text { (high-frequency } \\
\text { pulled down) }\end{array}$ & oscillator & also \\
\hline Distal colon & May be distal & $\begin{array}{l}\text { Pulled up } \\
\text { (high-frequency } \\
\text { pulled down) }\end{array}$ & oscillator & also \\
\hline
\end{tabular}

The origin of slow waves has usually been reported in the longitudinal layer of the small intestine, but it might also be found in some cells of the circular layer (Taylor, Daniel and Tomita, 1975). Spontaneous oscillations in the circular layer have been demonstrated in the cat colon (Christensen, Caprilli and Lund, 1969). Since oscillations can be recorded in both muscle layers, they must pass from one layer to the other. The existence of direct junctions has not been clearly demonstrated ; it is thus probable that the myenteric nervous plexus plays an important role in coupling the two muscles. Three types of intestinal movement - pendular, segmental and peristaltic - may be distinguished according to the variations in this coupling (see Gonella, 1971).

Intestinal smooth muscle is provided with a series of receptors for neurotransmitters and gastrointestinal peptides. Table 4 shows the receptors found in a particularly well known muscular zone, the lower oesophageal sphincter. While most of 
the usual neurotransmitter receptors are beginning to be well identified, those of the gastrointestinal hormones are far from definition and need further investigation.

\section{TABLE 4}

Muscular and nervous receptors found in the lower esophagus sphincier (LES) (from Goyal and Rattan, 1978 ; Gonella ef al., 1979 ; Cohen et al., 1979)

Effect on LES

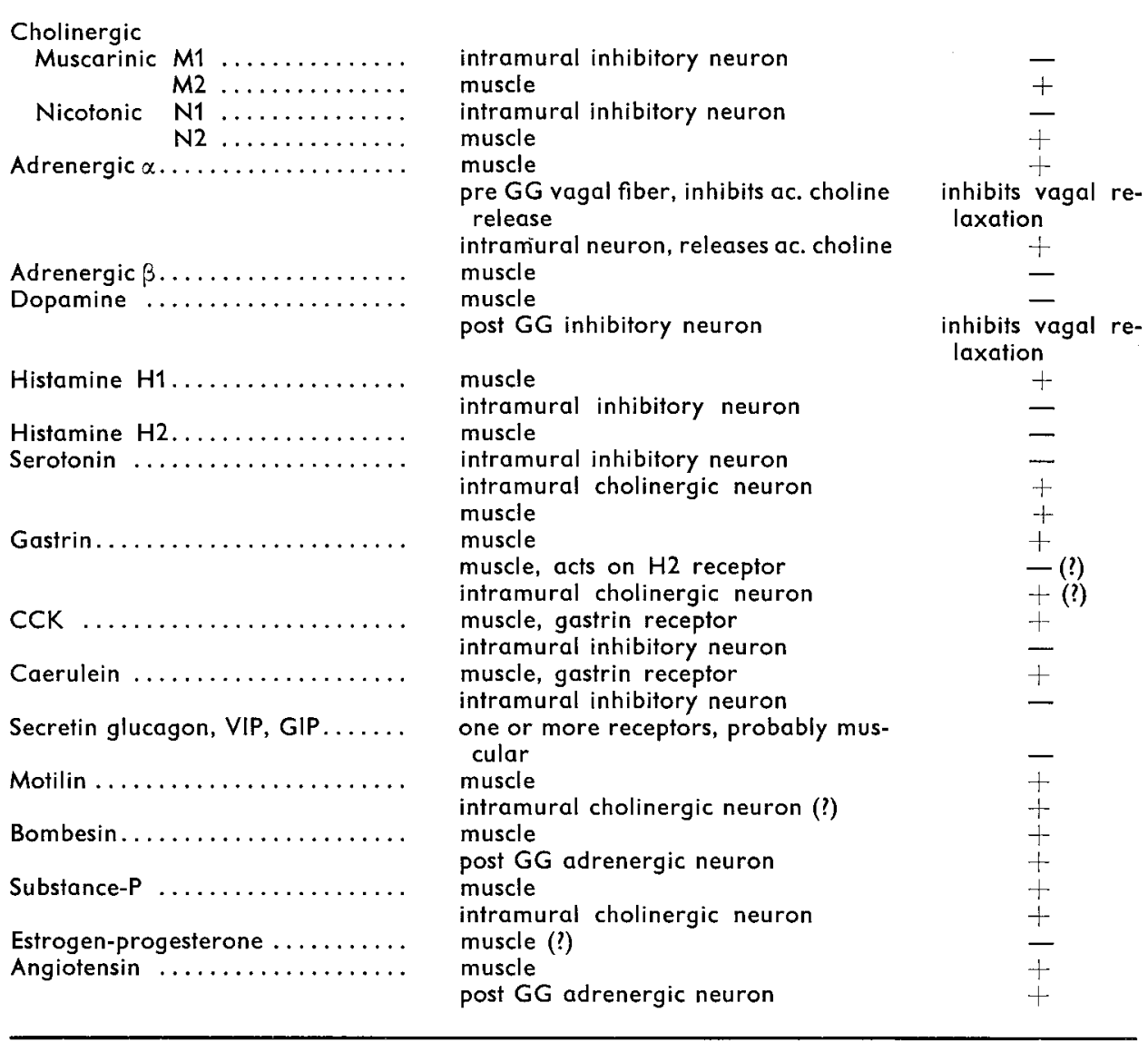

\section{Intrinsic innervation.}

This innervation consists of groups of cell bodies constituting the intramural ganglia ; these ganglia are interconnected exclusively by abundant, unmyelinated axons connecting the cell bodies. This whole forms the myenteric (Averbach's) and the submucosal (Meissner's) plexus of the wall. 
Some of the intramural neurons innervate the smooth muscles, while others are sensory neurons. A majority are interneurons establishing complex connections between the successive segments of the intestine.

The motor neurons innervating the smooth muscle do not terminate in neuromuscular junctions similar to those of the striated muscle. The fibers simply run near the smooth muscle cells without really contacting them. The neurotransmitters are stored as vesicles in the nodes distributed along the axon near the muscle cells. Moreover, nerve fiber density is low in relation to that of the muscle, indicating that most muscle fibers are not in the direct vicinity of a motor axon varicosity. The neurotransmitter released near a muscle fiber will probably excite several fibers, one after the other, through the intercellular gap junctions in the muscle.

Using electromyographical methods for recording neuromuscular excitatory junction potentials (depolarization) or inhibitory junction potentials (hyperpolarization), two main types of motor terminals are determined : excitatory terminals with acetylcholine as a transmitter and inhibitory terminals with one or more unknown, non-adrenergic neurotransmitters. These fibers could be purinergic (Burnstock, 1972, 1979), ATP-consuming, peptidergic, or sometimes dopaminergic (Valenzuela, 1976). Localized principally in Auerbach's plexus, the intrinsic integration system consists of a neuronal chain distally inhibiting the circular muscle in response to stretching. The nature of the interneurons in the chain is unknown but it is probably cholinergic since nicotine blockade inhibits distal chain transmission.

On the basis of intracellular microelectrode recordings, Hirst, Holman and McKirdy (1975) proposed a nervous circuit pattern for the descending inhibition causing peristalsis. Their results are limited morphologically and cannot be generalized to include all mammalian intestines having myogenic control systems because the experimental material chosen (the guinea-pig small intestine) is an exception to the rule since its smooth muscle does not generate slow waves and it has neurogenic electrical activity.

However, their work described a descending contractile inhibition as well as a descending stimulus, occurring only after some time-lag. The descending inhibitory route seems to pass entirely through the myenteric plexus, while part of the descending excitatory route would go by way of the submucosal plexus.

Descending inhibitory circuits have also been described in the rabbit small intestine (Daniel and Taylor, 1975) and in the esophagus and at the gastroduodenal junction (Daniel, 1977). Generalizing the system implies that intrinsic distal inhibition is the same throughout the gut. Its determination depends on the existence or absence of an active basal tone in the zone considered. When there is no basal tone, relaxation cannot occur ; only induced contractions can be inhibited by descending inhibitory pathways.

\section{Neurotransmitters of the intramural nervous system.}

Many synapses in the intramural nervous system are cholinergic and correspond to excitatory routes. There are probably several other neurotransmitters intervening in the inhibitory pathways. ATP, referred to as an important neurotransmitter of inhibitory neurons, probably exists but does not always have a predominant influence 
(Stockley, 1978). The existence of serotoninergic neurons may be considered as certain. These neurons have a specific $5 \mathrm{HT}$ receptor (a specific $5 \mathrm{HT}$-binding protein), contain tryptophane hydroxylase permitting $5 \mathrm{HT}$ synthesis from tryptophane and survive up to 3 weeks in organ culture (Gershon and Dreyfus, 1977), thus proving that their cell bodies are localized in the gut wall. It appears that they act by inhibiting the cholinergic excitatory pathway (Bulbring and Gershon, 1967 ; Gonella, 1978).

Besides these substances, there are many peptides in plexus nerve fibers (Polak and Bloom, 1978 ; Hokfelt ef al., 1978), but arguments in favor of their physiological role are still very limited at the present time.

A rich, probably intrinsic, network of VIP-immunoreactive nerves is found throughout the intestinal wall (Larsson ef al., 1976). VIP has been identified mainly in the cell bodies of the submucosal plexus, in the whole fiber network near the muscle cells and around the ganglionic cells of Auerbach's and Meissner's plexus.

Substance-P neurons have also been reported in the muscle layer and around ganglionic cell bodies of myenteric plexus (Pearse and Polak, 1975). The highest concentrations are found in the duodenum and the colon.

Somatostatin and Leu-enkephalin fibers are reported in the myenteric plexus. The persistence in organ culture of fibers reacting with antibodies raised against substance-P, somatostatin and Leu-enkephalin strongly suggests that the cell bodies of these neurons are to be found in the gut wall (Hokfelt et al., 1978).

\section{Sensory neurons.}

The functioning of the intrinsic nervous system implies the perception of sensory signals triggering control systems. Mechanoreceptors are found in the gut which adapt slowly or rapidly; some electrophysiological recordings have found cells which might fulfill this function in the intramural ganglia. When it was established that the peristaltic reflex of the guinea-pig intestine was maintained after removal of the mucosa, the idea prevailed that mechanoreceptors were probably grouped « in series 》 with the circular fibers and were thus closely associated with them. Daniel (1977) proposed «intermediary 》 cells as candidates for this function in the dog; these cells appearing to be glial cells in Schwann's sheath, but forming many gap junctions with the muscle cells and among themselves, would also have contact with the axons and varicosities of the myenteric plexus, and might sometimes contain actin-type filaments or neurotubules. The future will tell if they are mechanoreceptors or not.

\section{Fiber and cell body receptors of the intrinsic nervous system.}

The cell bodies and presynaptic elements of intrinsic nervous system neurons all have receptors which have not all been identified. Naturally, there are acetylcholine, noradrenalin and serotonin receptors. As these substances are mainly released near the receptors by the neural route, they usually act as ordinary neurotransmitters. However, circulating plasma catecholamines may reach a modulatory level acceptable to the accessible receptors. 
Neural gastrointestinal peptide receptors probably also exist in the intrinsic plexus. The circulating level of a peptide, or the rate of its paracrine release, then becomes important in modulating a nervous process, and peptidic action would be effected by the intermediary of intrinsic nervous system fibers. Peptides usually activate excitatory cholinergic mechanisms, but there are other possibilities. Among the peptides activating cholinergic fibers, motilin acts on the stomach (Tani et al., 1978) and the LES (Meissner ef al., 1976) and CCK affects the small intestine (Gonella, Salducci and Monges, 1973), while gastrin action on the LES is controversial, some authors reporting an atropine-sensitive mechanism and others none. Szurszewski (1975) has shown the action of gastrin on the intrinsic plexus of the dog gastric antrum. Octo-CCK would act on non-adrenergic inhibitory fibers of the cat LES (Behar and Biancani, 1977) and bombesin on adrenergic posiganglionic fibers releasing norepinephrine (Mukhopadhyay and Kunnemann, 1979).

These investigations, in full progress, are far from being concluded.

\section{Extrinsic nervous system.}

The extramural innervation is composed of parasympathetic and sympathetic fibers and includes motor efferent fibers and sensory afferent ones.

\section{Parasympathetic.}

The cell bodies of the parasympathetic efferent axons using the vagal pathway is in the brainstem and that of the axons using the pelvic nerve route is in the sacral segments of the spinal cord.

All the preganglionic axons, whether excitatory or inhibitory, are cholinergic. In the intestinal wall, these axons synapse with intramural neurons whether they are cholinergic excitatory or non-adrenergic inhibitory (NAI). Both types of postganglionic parasympathetic neurons act directly on the smooth fibers.

Vagal control of motor function is greater in the proximal part of the digestive tract (esophagus, stomach, upper small intestine) than in the distal part. However, all levels are somewhat independent from vagal control. Thus, in the smooth part of the cat, monkey and opossum esophagus, the main functions of peristalsis and LES relaxation may be obtained by stretching the isolated or extrinsically denervated esophagus. Cervical vagotomy induces motor disorders but does not abolish the esophageal peristalsis induced by stretching.

The distribution of efferent vagal fibers in the stomach has been thoroughly studied (Sarna and Daniel, 1975). The proximal fibers do not affect the slow or rapid electrical activity of the stomach. Like the chief cells and parietal cells of the fundic mucosa, they probably innervate the fundic muscle, inducing receptive relaxation or fundic contraction.

Further down, the segmental branches entering the gastric wall by the anterior and posterior nerves of Latarjet are segmentally distributed on the stomach. If they are severed sequentially from the proximal to the distal zone of the antrum, the contractions induced by stimulation disappear sequentially. Latarjet's nerves show some anterior-posterior cross-innervation by preganglionic fibers. The postganglionic 
neurons, on the contrary, are short and do not show this type of cross-innervation between the two sides of the stomach.

\section{Sympathetic nervous system.}

The cell bodies of the preganglionic efferent neurons of the sympathetic nervous system are in the dorsal and lumbar segments of the spinal cord. Their axon passes along the sympathetic ganglion column situated on either side of the spinal cord, then by thoracic and lumbar splanchnic nerves to synapse within the coeliac and mesenteric ganglia. The preganglionic neuron is cholinergic, while the postganglionic neuron is noradrenergic.

In most cases, the stimulation of noradrenergic fibers induces hyperpolarization of smooth muscle fibers and blockade of the cholinergic excitatory pathway; this corresponds to the usual cholinergic-adrenergic balance. Noradrenergic innervation seems more developed in the circular layer (Furness and Costa, 1974). Moreover, many noradrenergic fibers innervate the myenteric plexus. It would appear, however, that sympathetic terminals do not act directly on the cell body of neurons which are cholinergic activators, but inhibit acetylcholine release at a presynaptic site. Intracellular recording techniques have not evidenced enteric neurons whose membrane potential is modified either by noradrenaline or by sympathetic fiber stimulation (Gonella, 1978).

Sphincter innervation, particularly that of the lower esophagus sphincter, is different. Alpha adrenergic excitatory receptors are present on the smooth muscle cells of the LES and induce contraction. On the other hand, it has been recently shown in the cat that sympathetic stimulation and noradrenaline enhance cholinergic LES effects, probably by stimulating cholinergic myenteric neurons (Gonella, Niel and Roman, 1979 ; Niel, Gonella and Roman, 1979). This effect could not be demonstrated in the opossum (Fournet, Snape and Cohen, 1979).

\section{Afferent nerve fibers in the digestive tract.}

Many experiments have shown numerous afferent nerve fibers leaving the digestive tract and going towards the superior levels of the nervous system. Most of the data available have been collected in the cat in which the majority of sensory fibers first pass by the mesenteric nerves and are then divided between the vagal and thoracic splanchnic nerves (table 5). About 30 p. 100 of the mesenteric fibers connect with

\section{TABLE 5}

Sensory innervation of abdominal organs (compiled by Morrison, 1977). Number of afferent fibers counted in different nerves

\begin{tabular}{|c|c|c|c|c|}
\hline & \multirow[t]{2}{*}{ Vagal } & \multicolumn{2}{|c|}{ Splanchnic } & \multirow[t]{2}{*}{ Pelvic } \\
\hline & & Thoracic & Lumbar & \\
\hline $\begin{array}{l}\text { Myelinated fibers.......... } \\
\text { Unmyelinated fibers........ }\end{array}$ & $\begin{array}{r}400 \\
27000\end{array}$ & $\begin{array}{c}2500-15000 \\
13000\end{array}$ & 2500 & $\begin{array}{c}2200-3000 \\
?\end{array}$ \\
\hline
\end{tabular}


an efferent neuron in the inferior mesenteric and coeliac ganglia, thus constituting a short reflex pathway. The rest of the afferent fibers pass directly by the lumbar splanchnic nerve and the pelvic nerves.

Studies of degeneration show that most afferent neurons are situated in the enteric plexus. The cell body of some however is in the spinal ganglia.

To give an idea of the extent of the sensory fibers, more than 80 p. 100 of the fibers of the abdominal vagus in the cat and rabbit are afferent. A small percentage of these are medium-sized, myelinated fibers, while most are unmyelinated (Morrison, 1977).

The morphology of sensory DT terminals is not well known. Some of the fibers which may be considered as sensory are : small unmyelinated fibers going from the muscularis mucosae to the submucosal plexus ; fibers penetrating the muscularis mucosae, reaching the mucosa and terminating near the epithelial cells; networks of very small fibers with varicosities, present in the longitudinal muscles (cat stomach); spindle-shaped endings with terminal nodes penetrating the gastric smooth muscle (tension : Morrison, 1977). The duodenal zone is particularly rich in small fibers which are probably sensory.

The most studied receptors are sensitive to gut tension and stretching.

Stretching causes various rapid motor, secretory and behavioural responses (inhibition of food intake). Electrophysiological methods can be used to record the responses of the individual fibers connected to a receptor.

The mechanoreceptors described are of two types. Some are found in the muscle layers and are known as tension receptors «in series» with the muscle. They have been described in the stomach and small intestine as slowly adapting and connected to vagal or splanchnic fibers (see Mei, 1970 ; Leek, 1972 ; Paintal, 1973). Other mechanoreceptors found in the mucosal layers are stimulated by contractions of the muscularis mucosae and by tactile stimulation of the mucosa. They discharge irregularly and adapt rapidly (Paintal, 1957).

There are many chemoreceptors in the duodenum which are $\mathrm{pH}$, glucose or amino acid-sensitive (Iggo, 1957 ; Davison, 1972 ; Sharma and Nasset, 1962).

Recently, intestinal vagal glucoreceptors were studied in the cat (Mei, 1978). These receptors are connected to slowly adapting neurons corresponding to type-C fibers. They respond rapidly when the intestine is perfused with glucose or other sugars, are not sensitive to mechanical stimulation and do not seem to respond directly to the osmotic pressure of solutions, although showing increased response with the concentration. Their structure is unknown but they are probably situated near the mucosal cells. Some complexely branched fibers in the villi could represent glucosensitive endings.

Vagal thermoreceptors have also been described (El Ouazzani and Mei, 1979).

\section{Role of prevertebral ganglia.}

The prevertebral ganglia of the autonomic nervous system (solar plexus ganglia, inferior mesenteric ganglion) were considered for a long time as simple relays on the efferent sympathetic pathway destined for the abdominal organs.

Recently, however, intracellular neuronal activity recorded in the inferior mesenteric ganglion has shown that some postganglionic neurons receive synaptic influences 
from the colon, and even from the more oral zones of the digestive tract as well as from the central nervous system (Szurszewski and Weems, 1976). This autonomic ganglion would have three different functions : multiplication of efferent impulses, integration of afferent impulses and participation in peripheral reflex activity. It should be noted that since the same ganglionic neuron receives both centrifugal and centripetal impulses from the central nervous system by the peripheral reflex route, if is able to integrate these data (Szurszewski, 1977).

All autonomic ganglia do not function in the same way, and electrophysiological techniques are useful in determining whether a ganglionic cell receives one or more preganglionic fibers. In the hamster pelvic ganglia, each neuron receives only one to four preganglionic fibers, each fiber forming an «obligatory » synapse, i.e. an impulse on only one preganglionic fiber always triggers a postganglionic impulse. Moreover, many cells of that ganglion receive sympathetic (hypogastric nerve) as well as parasympathetic (pelvic nerve) afferent impulses. The functional significance of this process is unknown. Finally, the ganglion cell of these pelvic ganglia acts simply as a relay.

In contrast to these data, other prevertebral ganglia behave differently. Studies on the guinea-pig (Crowcroft and Szurszewski, 1971) or cat using cellular responses of neurons of the inferior mesenteric ganglion obtained by microelectrodes, show that each neuron receives impulses from at least 40 different identifiable preganglionic fibers. Most of these fibers form « weak » synapses, individually insufficient for releasing an action potential. The action potential occurs on the postganglionic axon only when the sympathetic potentials accumulate in space or time. Integration is thus a function of these neurons.

The neurons of the inferior mesenteric ganglion also receive sensory impulses from the colon through the lumbar colic nerves. These impulses from slowly adapting mechanoreceptors, whose discharge rhythm seems correlated with the state of endoluminal pressure and propulsive motor activity, are inhibited when tetrodotoxin is perfused into the colon (Szurszewski, 1977). These mechanoreceptors constifute the afferent branch of a reflex loop whose efferent is the noradrenergic postganglionic neuron. This neuron acts (i) on the intramural excitatory neurons by decreasing their acetylcholine release, (ii) on the muscle by reducing contractile activity and (iii) on the mechanoreceptors themselves by desensitizing them (Szurszewski and Weems, 1976).

A last function of the prevertebral ganglia would be to connect the functions of the different zones of the digestive tract. This has been shown between the distal and proximal colon by the cross-innervation of inferior and superior mesenteric ganglia.

\section{Role of the central nervous system.}

This role is evident in view of the high number of afferent impulses taking the vagosympathetic routes, and the marked effects of stimulation of the efferent fibers destined for the digestive tract. However, there are few data on the way in which information is treated and transformed in the central nervous system.

The hypothalamic glucoreceptors causing central molor stimulation have been siudied thoroughly. This system is easily modulated by insulin hypoglycemia or by 2-deoxyglucose (2-DG) which, in competition with glucose, produces intra-cellular 
cyloglucopenia in spite of the hyperglycemia following nervous stimulation of the adrenals.

2-DG has many effects on the digestive tract, stimulating secretion, motility and hyperphagic response and activating hyperglycemia and hypothermia (Muller, Cocchi and Forni, 1971 ; Muller et al., 1974). The motor effects of 2-DG are particularly evident in the stomach where they are partially correlated with secretory effects (Boiselle, Rozé and Vatier, 1977).

The existence of a pathway connecting the hypothalamus and the vagal nerve indicates that there may be many modulating factors.

A pharmacological study of the modulation of this pathway has produced positive results on gastric and pancreatic secretion (Rozé ef al., 1978, 1979) and it should also be fruitful as regards motility (Burks, 1978).

The central effects of morphine on gastrointestinal motility have been studied by injecting doses too low to be active in systemic injection into the cerebral ventricles of the conscious cat. This drug induced vomiting and also triggered a characteristic sequence of intestinal myoelectrical activity showing an intense burst of spike potentials moving in the aboral-oral direction (Stewart, Burks and Weisbrodt, 1977a). The effect is not specific to morphine since it can also be obtained after intraventricular injections of apomorphine and adrenaline. In all cases, the process is controlled by the emetic center.

Moreover, intraventricular injection of smaller doses of morphine, which do not produce vomiting and are inactive by the systemic route, increases spike potentials at all levels of the small intestine (Stewart, Weisbrodt and Burks, 1977b). This effect is inhibited by small doses of naloxone by the IVT route, indicating that morphine may produce intestinal contractions by acting on cerebral structures (Bueno and Ruckebusch, 1978). These motor changes may affect transit; in the rat doses of morphine, which would be ineffective when given by the systemic route, inhibit small intestine transit when given by IVT (Parolaro, Sala and Gori, 1977 ; Stewart, Weisbrodt and Burks, 1977c). Transit inhibition is reduced by vagotomy and by naltrexone given by IVT.

It is certain that opiates modify intestinal motility by direct organ effect. However, both central and peripheral mechanisms may play a role in vivo.

The actions reported with morphine encourage research on endogenous opioid peptides, endorphins and enkephalins (Konturek, 1978). Pascaud et al. (1979) recently showed a decrease in antral contractions and an increase in colic motility in the rat under the effect of $\beta$-endorphin, Met-enkephalin and the long-acting analog, D-Ala Met-enkephalinamide, when given by IVT.

Other substances probably also affect central motility. Injecting small amounts of TRH (thyrotropin-releasing hormone) by IVT causes intense stimulation of colonic motility (Smith et al., 1977).

As emphasized previously, the fact that the brain and the gut have common peptides, such as somatostatin, VIP, neurotensin, CCK-like, gastrin-like and substance $P$, is a reason for continuing to explore the central mechanisms of the brain-gut relationship. 
Résumé. Le panorama changeant de la physiologie gastro-intestinale est actuellement dominé par le concept de régulation neuro-endocrine, et les phénomènes moteurs dans le tube digestif n'échappent pas à cette règle.

A la fin du XIXe siècle le contrôle nerveux de la digestion paraît évident à la suite des travaux de Pavlov. Puis en 1902 Bayliss et Starling découvrent la sécrétine et l'hormonologie digestive prend un tel essor que l'influence du système nerveux se trouve pratiquement oubliée des nouveaux endocrinologues digestifs. Il faut pratiquement attendre 1975 avec la mise en évidence de la somatostatine dans les cellules $D$ gastro-intestinales et pancréatiques pour qu'explose subitement une énorme vague d'intérêł immunochimique, embryologique et physiologique pour les peptides présents à la fois dans le cerveau et le tube digestif (somatostatine, VIP, gastrine, octo-CCK, neurotensine, enkephalines...). De plus certains de ces peptides sont trouvés à la fois dans des fibres nerveuses et des cellules de type endocrine, posant de nouvelles questions sur les origines et le fonctionnement de ce système neuro-endocrine. Il faut admettre qu'un peptide hormonal peut agir au moins de trois façons différentes : comme neuro-transmetteur peptidergique, comme substance à action locale dite paracrine, comme hormone circulante.

Grâce à ces découvertes, tous les physiologistes sont obligés de reconnaître que les facteurs nerveux et les facteurs humoraux sont d'une égale importance dans la régulation digestive, et qu'ils sont de plus difficilement dissociables en raison de leur intrication : la situation de potentialisation neuro-endocrine paraît en effet de règle dans les conditions physiologiques.

La régulation de la motricité digestive n'échappe pas à cette loi générale. Le tableau est cependant complexe. Le muscle lisse intestinal possède son activité myogène autonome et ses récepteurs propres. Son innervation comprend les plexus de la paroi (intrinsèque), les ganglions du plexus solaire et mésentérique inférieur qui intègrent certaines informations ef le niveau du système nerveux central, « câblé » par les voies vagale et sympathique. Sur cette structure se greffent les actions hormonales, chaque peptide ayant en théorie la possibilité d'agir à chacun des niveaux d'organisation précédents, y compris en participant à une éventuelle transmission synaptique.

Chaque effecteur se trouve ainsi contrôlé par le résultat local de la somme des concentrations des nombreux agonistes et antagonistes présents, peptides ou neurotransmetteurs, dont chacun n'est souvent que relativement spécifique des récepteurs de l'effecteur, compte tenu des parentés partielles de structure des peptides mis en jeu.

L'étude analytique des différents facteurs agissant sur le muscle gastro-intestinal est nécessaire avant de construire le tableau de synthèse, qui seul représentera la physiologie. Dans la plupart des cas nous n'en sommes encore qu'à la première partie, analytique, de ce programme. En tout cas, une séparation complète des facteurs nerveux et des facteurs humoraux n'est plus possible : leur interaction est permanente sous forme d'une régulation neuro-endocrine.

\section{Références}

ARIMURA A., SATO H., DUPONT A., NISHI N., SCHALLY A. V., 1975. Somatostatin : Abundance of immunoreactive hormone in rat stomach and pancreas. Science, 189, 1007-1009.

BEHAR J., BIANCANI P., 1977. Effect of cholecystokinin-octapeptide on lower esophageal sphincter. Gastroenterology, 73, 57-61.

BOISELLE J. C., ROZÉ C., VATIER J., 1977. Etude comparative de la motricité et de la sécrétion gastriques stimulées par le 2-deoxy-D-glucose chez le chien. Gastroenterol. clin. biol., 1, 345-352.

BROWN J. C., COOK M. A., DRYBURGH J. R., 1973. Motilin, a gastric motor stimulating polypeptide : The complete amino acid sequence. Can. J. Biochem., 51, 533-537.

BROWN J. C., DRYBURGH J. R., 1971. A gastric inhibitory polypeptide. Il. The complete amino acid sequence. Can. J. Biochem., 49, 867-872.

BROWN M., RIVIER J., KOBAYASHI R., VALE W., 1978. Neurotensin-like and bombesin-like peptides : CNS distribution and actions, 550-558. In Bloom S. R., Gut Hormones, Churchill Livingstone, Edinburgh. 
BRYANT M. G., POLAK J. M., MODLIN I., BLOOM S. R., ALBUQUERQUE R. H., PEARSE A. G. E., 1976. Possible dual role for vasoactive intestinal peptide as gastrointestinal hormone and neurotransmitter substance. Lancet, I, 991-993.

BUENO L., RUCKEBUSCH Y., 1978. Origine centrale de l'action excito-motrice de l'intestin par la morphine. C. R. Soc. Biol., 172, 972-977.

BULBRING E., GERSHON M. D., 1967. 5-hydroxytryptamine participation in the vagal inhibitory innervation of the stomach. J. Physiol. Lond., 192, 823-846.

BURKS T. F., 1978. Central sites of action of gastrointestinal drugs. Gastroenterology, 74, 322-324.

BURNSTOCK G., 1972. Purinergic nerves. Pharmacol. Rev., 24, 509-581.

BURNSTOCK G., 1979. Non-adrenergic, non-cholinergic enteric neurones : Their roles and interactions with classical nerves, 481-492. In ROSSELIN G., FROMAGEOT P., BONFILS S., Hormone receptors in digestion and nutrition, Elsevier/North Holland Biomed, Press, Amsterdam, New York.

CARRAWAY R., LEEMAN S. E., 1975. The amino-acid sequence of a hypothalamic peptide, neurotensin. J. biol. Chem., 250, 1907-1911.

CHANG M. M., LEEMAN S. E., NIALL H. D., 1971. Amino-acid sequence of substance-P. Nature, (New Biol.), 232, 86-87.

CHAYVIALLE J. A., DESCOS F., MIYATA M., RAYFORD P. L., THOMPSON J. C., 1979. Molecular forms of somatostatin in acetic extracts of pancreas and gastro-intestinal mucosa, 109-114. In ROSSELIN G., FROMAGEOT P., BONFILS S. Hormone receptors in digestion and nutrition, Elsevier/North Holland Biomed. Press.

CHRISTENSEN J., CAPRILLI R., LUND G. F., 1969. Electric slow waves in circular muscle of cat colon. Am. J. Physiol., 217, 771-776.

CROWCROFT P. J., SZURSZEWSKI J. H., 1971. A study of the inferior mesenteric and pelvic ganglia of guinea-pigs with intracellular electrodes. J. Physiol London, 219, 421-441.

DANIEL E. E., 1977. Nerves and motor activity of the gut, 154-196. In Brooks F. P., EVERS P. W. Nerves and the gut, C. B. Slack Inc, Thorofare, N. J.

DANIEL E. E., TAYLOR G. S., 1975. Junction potentials and control of motility of the small intestine. Proc. 5th int. Symp. on GI motility, G. VANTRAPPEN Ed., Typoff Press, Herentals Belgium, 213-218.

DAVISON J. J., 1972. Response of single vagal afferent fibres to mechanical and chemical stimulation of the gastric and duodenal mucosa in cats. J. exp. Physiol., 57, 405-416.

DOCKRAY G. J., 1976. Immunochemical evidence of cholecystokinin-like peptides in brain. Nature 264, 568-570.

EL OUAZZANI T., MEI N., 1979. Mise en évidence électrophysiologique des thermorécepteurs vagaux dans la région gastro-intestinale, leur rôle dans la régulation de la motricité digestive. Expl. Brain Res., 34, 419-434.

ERSPAMER V., MELCHIORRI P., FALCONIERI-ERSPAMER C., NEGRI L., 1978. Polypeptides of the amphibian skin active on the gut and their mammalian counterparts, 51-64. In SPERANZA V., BASSO N., LEZOCHE E., GROSSMAN M. I. ; Gastrointestinal hormones and pathology of the digestive system, Plenum Press, New York.

FOURNET J., SNAPE W. J., COHEN S., 1979. The cholinergic component of basal lower esophageal sphincter pressure. 7 th int. Symp. on gastrointestinal motility, lowa City, Abstr. Vol., p. 4.

FURNESS J. B., COSTA M., 1974. The adrenergic innervation of the gastro-intestinal tract. Ergebn. Physiol., 69, 1-51.

GERSHON M. D., DREYFUS C. F., 1977. Serotonergic neurons in the mammalian gut, 197-206. In BROOKS F. P., EVERS P. W., Nerves and the gut. CBS Inc. Thorofare, N. J.

GONELLA J., 1971. Etude électromyographique des contractions segmentaires et péristaltiques du duodénum de lapin. Pflügers Arch. 322, 217-234.

GONELLA J., 1978. La motricité digestive et sa régulation nerveuse. J. Physiol. Paris, 74, 131140.

GONELLA J., NIEL J. P., ROMAN C., 1979. Sympathetic control of lower œsophageal sphincter motility in the cat. J. Physiol London, 287, 177-190.

GONELLA J., SALDUCCI J., MONGES H., 1973. Mode d'action de la cholecystokinine pancreozymine sur le duodenum de lapin in vifro. Etude électromyographique. Biol. Gasiroentérol Paris, 6, 365-366. 
GOYAL R. K., RATTAN S., 1978. Neurohumoral, hormonal and drug receptors for the lower esophageal sphincter. Gastroenterology, 74, 598-619.

GREGORY H., HARDY P. M., JONES D. S., 1964. Structure of gastrin. Nature, 204, 931-933.

HAZLEWOOD R. L., TURNER S. D., KIMMEL J. R., POLLOCK H. G., 1973. Spectrum effects of a new polypeptide (third hormone ?) isolated from the chicken pancreas. Gen. comp. Endocrinol., 21, 485-497.

HIRST G. D. S., HOLMAN M. E., MCKIRDY H. C., 1975. Two descending pathways activated by distension of guinea pig small intestine J. Physiol. London, 244, 113-127.

HOKFELT T., SCHULTZBERG M., JOHANSSON O., LJUNGDAHL A., ELFVIN L., ELDE R., TERENIUS L., NILSSON G., SAID S., GOLDSTEIN M., 1978. Central and peripheral peptide producing neurons, 423-433. In BLOOM S. R., Gut hormones, Churchill Livingstone, Edinburgh.

IGGO A., 1957. Gastric mucosal chemoreceptors with vagal afferent fibres in the cat. Q. J. expl. Physiol., 42, 398-409.

KITABGI P., CARRAWAY R., LEEMAN S. E., 1976. Isolation of a tridecapeptide from bovine intestinal tissue and its partial characterization as neurotensin. J. biol. Chem., 251, 7053-7058.

KONTUREK S. J., 1978. Endogenous opiates and the digestive system. Scand. J. Gostroent., 13, 257-261.

LARSSON L. I., FAHRENKRUG J., SCHAFFALITZKY de MUCKADELL O., SUNDLER F., HAKANSON R., REHFELD J. F., 1976. Localisation of vasoactive intestinal polypeptide (VIP) to central and peripheral neurons. Proc, nat. Acad. Sci. USA., 73, 3197-3200.

LEEK B. F., 1972. Abdominal visceral receptors, 113-160. In NEIL E., Handbook of sensory physiology, vol. III/1, Enteroceptors, Springer Verlag Berlin, Heidelberg. New York.

LIN T. M., CHANCE R. E., EVANS D., 1973. Stimulatory and inhibitory actions of a bovine pancreatic polypeptide (BPP) on gastric and pancreatic secretions of dogs. Gastroenterology, 64, 865.

MEI N., 1970. Mécanorécepteurs vagaux digestifs chez le chat. Expl. Brain Res., 11, 480-501.

MEI N., 1978. Vagal glucoreceptors in the small intestine of the cat. J. Physiol. London, 282, 485-506.

MEISSNER A. J., BOWES K. L., ZWICK R., DANIEL E. E., 1976. Effect of motilin on the lower cesophageal sphincter. Gut, 17, 925-932.

MORLEY J. E., GARVIN T. J., PEKARY A. E., HERSHMAN J. M., 1977. Thyrotropin-releasing hormone in the gastrointestinal tract. Biochem. biophys. Res. Commun., 79, 314-318.

MORRISON J. F. B., 1977. The afferent innervation of the gastrointestinal tract, 297-326. In BROOKS F. P., EVERS P. W., SLACK C. B., Nerves and the gut. Thorofare, N. J.

MUKHOPADHYAY A. K., KUNNEMANN M., 1979. Mechanism of lower œsophageal sphincter stimulation by bombesin in the opossum. Gastroenterology, 76, 1409-1414.

MULLER E. E., COCCHI D., FORNI A., 1971. A central site for the hyperglycemic action of 2-deoxy $D$ glucose in mouse and rat. Life Sci., 10, 1057-1067.

MULLER E. E., PECILE A, COCCHI D., OLGIATI V. R., 1974. Hyperglycemic or feeding response to glucoprivation and hypothalamic glucoreceptors. Amer. J. Physiol., 226, 1100-1109.

MUTT V., JORPES E., 1971. Hormonal polypeptides of the upper intestine. Biochem J., 125, 57P-58P.

MUTT V., JORPES J. E., MAGNUSSON S., 1970. Structure of secretin. The amino acid sequence. Eur. J. Biochem., 15, 513-519.

MUTT V., SAID S. I., 1974. Structure of the porcine vasoactive intestinal octacosapeptide. The amino acid sequence. Use of kallikrein in its determination. Eur. J. Biochem., 42, 581-589.

NIEL J. P., GONELLA J., ROMAN C., 1979. Evidence of a cholinergic mechanism in the sympathetic control of cat's LES. 7th int. Symp. on gastrointestinal motility, lowa City, Abstr. Vol., p. 5.

PAINTAL A. S., 1957. Responses from mucosal mechano-receptors in the small intestine of the cat. J. Physiol., 139, 353-368.

PAINTAL A. S., 1973. Vagal sensory receptors and their reflex effects. Physiol. Rev., 53, 159-227.

PAROLARO D., SALA M., GORI E., 1977. Effect of intracerebroventricular administration of morphine upon intestinal motility in rat and its antagonism with naloxone. Europ. J. Pharmacol., 46, 329-338.

PASCAUD X. B., GENTON M. G., REMOND G., VINCENT M., 1979. Effects of morphinomimetic peptides upon gut motility in anesthesized rats. Europ. J. Pharmacol. (submitted for publication).

PEARSE A. G. E., POLAK J. M., 1975. Immunocytochemical localisation of substance $P$ in mammalian intestine. Histochemistry, 41, 373-375.

POLAK J. M., BLOOM S. R., 1978. Peptidergic innervation of the gastrointestinal tract. Adv. expl. Med. Biol., 106, 27-49. 
POLAK J. M., BLOOM S. R., SULLIVAN S. N., FACER P., PEARSE A. G. E., 1977. Enkephalin-like immunoreactivity in the human gastrointestinal tract. Lancef, 1, 972-974.

PRADAYROL L., CHAYVIALLE J., MUTT V., 1978. Pig duodenal somatostatin : extraction and purification. Mefabolism, 27, suppl. 1, 1197-1200.

ROZÉ C., CHARIOT J., LA TOUR J. de, SOUCHARD M., VAILLE C., 1979. Endorphin and enkephalin effects on basal and vagally stimulated pancreatic secretion in rats, 513-516. In ROSSELIN G., FROMAGEOT P., BONFILS S. Hormone receptors in digestion and nutrition, Elsevier/North Holland Biomed Press, Amsferdam, New York.

ROZÉ C., CHARIOT J., LA TOUR J. de, SOUCHARD M., VAILLE C., DEBRAY C., 1978. Methadone blockade of 2-deoxyglucose-induced pancreatic secretion in the rat. Evidence for a central site of action. Gastroenterology, 74, 215-220.

SARNA S. K., DANIEL E. E., 1975. Vagal control of gastric electrical control activity and motility. Gastroenterology, 68, 301-308.

SARNA S. K., DANIEL E. E., KINGMA Y.J., 1971. Stimulation of slow-wave electrical activity of small intestine. Am. J. Physiol., 221, 166-175.

SARNA S. K., DANIEL E. E., KINGMA Y.J., 1972. Stimulation of electrical control activity of the stomach by an array of relaxation oscillators. Am. J. Dig. Dis., 17, 299-310.

SHARMA K. N., NASSET E. S., 1962. Electrical activity in mesenteric nerves after perfusion of gut lumen. Am. J. Physiol., 202, 725-730.

SMITH J. R., LA HANN T. R., CHESNUT R. M., CARINO M. A., HORITA A., 1977. Thyrotropinreleasing hormone : Stimulation of colonic activity following intracerebroventricular administration. Science, 196, 660-662.

SPIESS J., VALE W., 1978. Evidence for larger forms of somatostatin in pigeon pancreas and rat brain. Mefabolism, 27, suppl. 1, 1175-1178.

STEWART J. J., BURKS T. F., WEISBRODT N. W., 1977a. Intestinal myoelectric activity after activation of the central emetic mechanism. Am. J. Physiol., 233, E131-E137.

STEWART J. J., WEISBRODT N. W., BURKS T. F., 1977b. Centrally mediated intestinal stimulation by morphine. J. Pharmacol. exp. Ther., 202, 174-181.

STEWART J. J., WEISBRODT N. W., BURKS T. F., 1977c. Centrally mediated inhibition of intestinal transit by morphine. Pharmacologist, 19, 146.

STOCKLEY H., 1978, 2.2' Pyridylisatogen antagonizes adenosine 5'-triphosphate but not nerve-mediated relaxations in human isolated taenia coli, 145-150. In DUTHIE H. L., Gastrointestinal motility in health and disease, MTP Press Ltd, Lancester-England.

STUDER R. O., TRZECIAK A., LERGIER W., 1973. Isolierung und Aminosaüresequenz von Substans $P$ aus Pferdedarum. Helv. chim. Acto, 56, 860-866.

SZURSZEWSKI J. H., 1975. Mechanism of action of pentagastrin and acetylcholine on the longitudinal muscle of the canine antrum. J. Physiol. London, 252, 335-361.

SZURSZEWSKI J. H., 1977. Toward a new view of prevertebral ganglion, 244-260. In BROOKS F. P. EVERS P. W., SLACK C. B. Nerves and the gut, Thorofare, N.J.

SZURSZEWSKI J. H., WEEMS W. A., 1976. A study of peripheral input to and its control by postganglionic neurons of the inferior mesenteric ganglion. J. Physiol. London, 256, 541-556.

TANI M., SUGAWARA K., KATOH M., MANABE M., AKASAKA Y., KAWAI K., 1978. Effect of synthetic motilin on gastric motility. Nippon Heikat. Gakkai Zasshi, 14, 55-62.

TAYLOR G. S., DANIEL E. E., TOMITA T., 1975. Origin and mechanism of intestinal slow waves. In 5 th int. Symp. on GI motility, Leuven, Belgium, G. VANTRAPPEN, H. O. AGG Eds, Typoff Press Herentals, Belgium, 102-106.

VALENZUELA J. E., 1976. Dopamine as a possible neuro-transmitfer in gastric relaxation. Gastroenterology, 71, 1019-1022.

VON EULER V. S., GADDUM J. H., 1931. An unidentified depressor substance in certain tissue extracts. J. Physiol. London, 72, 74-87.

YANAIHARA C., SATO H., YANAIHARA N., NARUSE S., FORSSMANN W. G., HELMSTAEDTER V., FUJITA T., YAMAGUCHI K., ABE K., 1978. Motilin, substance $P$ and somatostatin-like immunoreactivities in extracts from dog, tupaia and monkey brain and GI tract, 269-283. In SPERANZA V., BASSO N., LEZOCHE E., GROSSMAN M. I. Gastrointestinal hormones and pathology of the digestive system. Plenum Press, N. Y. 